\title{
Pengaruh Gear Ratio Transmisi dan Grade Jalan Terhadap Fuel Consumption Truck Batubara dengan Pendekatan Regresi Linier Berganda
}

\author{
Arif Nuryono* ${ }^{* 1}$ \\ Teknik Industri Fakultas Teknik, Universitas Bhayangkara Jakarta \\ e-mail: *1 arif.nuryono@dsn.ubharajaya.ac.id
}

\begin{abstract}
Transmission Gear Ratio usually affects torque and speed. The effect on fuel consumption for coal trucks with a capacity of 20 tons needs technical analysis and experiment to obtain actual data. In the experiment process using a standard transmission issued by the factory that is with 8 forward speed and 1 reverse speed. Experiment is done by comparing the calculation of fuel consumption with the use of transmission. Tests carried out using 2 dump trucks, 6 times sampling, 8-Speed, $30 \mathrm{~km}$ distance, with variations in the grade 8 segments and loads. From the results of testing and calculation of fuel consumption with parameter 8 variations in road grade and loaded, different fuel usage is obtained for each road segment and in load or empty conditions. When high grade fuel consumption also increases, when loaded conditions fuel consumption increases. Road grade and loaded conditions affect the use of fuel consumption. The use of transmission speed or gear ratio also affects fuel consumption.
\end{abstract}

Keywords: Transmission gear ratio, grade of road, fuel consumption

\begin{abstract}
ABSTRAK
Gear Ratio pada transmisi rata-rata berpengaruh terhadap torsi dan kecepatan. Sedangkan pengaruh terhadap pemakaian bahan bakar atau fuel consumption untuk truk batubara kapasitas 20 ton ini perlu analisis secara teknis dan pengujian lapangan untuk mendapatkan data secara aktual. Dalam proses pengujian menggunakan transmisi standar yang dikeluarkan oleh pabrik yaitu dengan 8 speed maju dan 1 speed mundur. Pengujian dilakukan dengan membandingkan antara perhitungan fuel consumption dengan penggunaan transmisi. Pengujian dilakukan dengan menggunakan 2 dump truck, 6 kali sampling, 8-Speed, jarak tempuh $30 \mathrm{~km}$, dengan variasi grade jalan dengan 8 segmen dan beban muatan. Dari hasil pengujian dan perhitungan fuel consumption dengan parameter 8 variasi grade jalan dan beban muatan, diperoleh perbedaan pemakaian bahan bakar untuk tiap segmen jalan dan dalam kondisi muatan atau kosongan. Saat grade tinggi pemakaian bahan bakar juga meningkat, saat kondisi loaded pemakaian bahan bakar meningkat. Kondisi grade jalan dan muatan mempengaruhi pemakaian bahan bakar. Pemakaian speed atau gear ratio transmisi juga mempengaruhi fuel consumption.
\end{abstract}

Kata Kunci: Gear Ratio Transmisi, Grade Jalan, Fuel Consumption

\section{PENDAHULUAN}

Dalam usaha di bidang pertambangan batubara ada dua hal yang menjadi tujuan untuk mencapai profit atau keuntungan yaitu peningkatan revenue (pendapatan) dan mengurangi cost (biaya operasional). Pertambangan adalah industri padat modal yang sangat, dan diketahui fakta bahwa pemanfaatan peralatan dan estimasi akurat dari pemanfaatan ini sangat penting karena manajer tambang ingin memanfaatkan peralatan mereka seefektif mungkin untuk mendapatkan kembali awal investasi mereka serta mengurangi total biaya produksi. (Elevli, 2010). Upaya-upaya untuk memaksimalkan produktivitas akan dapat 
meningkatkan produksi (paduloh et al., 2020), sehingga pada gilirannya akan menghasilkan pengurangan biaya, dan hal ini paling sering dilakukan oleh sistem fleet management (Nel et al., 2011). Hilangnya ketersediaan peralatan yang terlibat kerugian dalam produksi baik dalam hal apapun terjadi kegagalan peralatan karena teknis atau alasan lain atau dalam kasus penghentian minor peralatan selama operasi. (Waqas et al., 2015). Dalam operasi penambangan open pit, sistem penanganan material terdiri dari pemuatan, pengangkutan dan pembuangan. Sistem truck-shovel paling umum digunakan dalam penambangan terbuka. Shovel-truck mengacu pada sistem penambangan muatanangkut-dump, yang melibatkan setiap kombinasi unit muat dan truk (Ram Prasad Choudhary, 2015). Yang mempengaruhi biaya operasional pengangkutan overburden dan batubara salah satunya adalah biaya pemakaian fuel alat hauling yaitu dump truck. Besar kecilnya fuel yang dibutuhkan tergantung banyak faktor, diantaranya adalah kondisi jalan yang dilalui (faktor eksternal), kondisi unit (faktor internal), skill operator (faktor internal) dan sebagainya. Faktor eksternal yang timbul kemungkinan akan sulit kita kendalikan, tetapi faktor internal yang timbul masih bisa kita kendalikan guna mencapai kondisi unit atau dump truck yang prima, salah satunya dengan pemakaian suku cadang yang handal, modifikasi komponen atau power train. Seperti halnya penggunaan transmisi yang dimanifestasikan menjadi gear ratio transmisi, hal ini tentunya akan mempengaruhi juga pemakaian bahan bakar. Penelitian ini mengambil lokasi tambang di wilayah Kalsel, dengan obyek adalah DT Hino karena alat ini yang fokus mengangkut batubara. Fenomena yang terjadi adalah grade jalan yang bervariasi sehingga berdampak kepada penggunaan transmisi. Oleh sebab itu pendekatannya adalah bagaimana pemakaian gigi yang tepat saat menghadapi kondisi jalan yang ber-contour. Pendekatan lain adalah seberapa besar pengaruhnya pemakaian gigi transmisi terhadap pemakaian fuel.

\section{METODE PENELITIAN}

\subsection{POWER TRAIN (TRANSMISI)}

Tanpa transmisi, tenaga motor yang digunakan pada kendaraan sudah mampu menggerakan kendaraan dengan kecepatan tertentu pada kondisi jalan rata. Namun pada saat kendaraan menaiki tanjakan, atau pada saat menggerakan kendaraan pertama sekali (dari kodisi diam untuk bergerak), motor mungkin akan mati. Agar tenaga yang ada pada motor dapat memenuhi segala kebutuhan tenaga pada semua tingkat beban, maka kendaraan (truck) dilengkapi dengan transmisi. Transmisi berfungsi untuk meningkatkan daya motor sesuai dengan beban yang ada. (Salim, H.A. Abbas. 2012)

1. Jenis-Jenis Transmisi

- Transmisi standar : pada posisi tuas persneling tertinggi putaran input sama dengan putaran output.

- Transmisi overdrive : pada posisi tuas perseneling pada posisi tertinggi putaran output lebih tinggi di bandingkan putaran input.

- Transmisi Otomatis : transmisi yang mampu menyesuaikan out-putnya (daya dan kecepatan) sesuai dengan kebutuhan kendaraan secara otomatis. Transmisi otomatis tidak memerlukan pedal kopling, sebagai pengantinya digunakan kopling fluida yang ditempatkan antara motor dan transmisi. (Salim, H.A. Abbas. 2012)

2. Teori Roda Gigi (Transmisi)

a. Perbandingan putaran transmisi (speed ratio), dinyatakan dalam notasi : i

$$
\begin{aligned}
& \text { Speed ratio }: i=\frac{n 1}{n 2}=\frac{d 2}{\pi 1}=\frac{z 2}{\approx 1} \ldots \ldots . .(1) \\
& \text { Jika } \quad: i<1=\text { transmisi roda gigi inkrisi } \\
& i>1=\text { transmisi roda gigi } \\
& \text { reduksi }
\end{aligned}
$$

(Hagendoorm, J.J.M 1992)

b. Jumlah roda gigi

$$
\begin{aligned}
& \mathrm{Z}=\frac{D}{m} \\
& \text { Di mana : } \\
& \mathrm{Z}=\text { Jumlah gigi pada roda gigi (buah). } \\
& \mathrm{D}=\text { Diameter jarak bagi }(\mathrm{mm}) \text {. } \\
& \mathrm{m}=\text { Modul gigi }(\mathrm{mm}) \text {. } \\
& \text { (Sularso, 2002). }
\end{aligned}
$$


Harga modul diambil dari tabel harga modul standar JIS B 1701 - 1973 (Sumber : Sularso, 2002).

c. Diameter lingkaran kepala

$\mathrm{Dk}=(\mathrm{Z}+2) \mathrm{x} \mathrm{m}$

Di mana :

$\mathrm{Dk}=$ Diameter lingkaran kepala $(\mathrm{mm})$ (Sularso, 2002).

d. Diameter lingkaran kaki

$\mathrm{Dg}=\mathrm{Z} \times \mathrm{m} \times \cos \alpha$

Di mana :

$\mathrm{Dg}=$ Diameter lingkaran kaki $(\mathrm{mm})$. $\alpha=$ Sudut tekan (Derajat).

(Sularso, 2002).

e. Kecepatan keliling

$\mathrm{V}=\frac{\pi \times D \times n}{60 \times 10 n n}$

Di mana :

$\mathrm{V}=$ Kecapatan keliling untuk tiap roda gigi $(\mathrm{m} / \mathrm{s})$.

$\mathrm{D}=$ Diameter jarak bagi untuk tiap roda gigi (mm).

$\mathrm{n}=$ Putaran poros (rpm).

(Sularso, 2002).

f. Gaya tangensial

$\mathrm{Ft}=\frac{102 \times \mathrm{Pd}}{\mathrm{v}}$

Di mana :

$\mathrm{Ft}=$ Gaya tangensial $(\mathrm{kg})$.

$\mathrm{Pd}=$ daya rencana $(\mathrm{kW})$.

(Sularso, 2002).

\section{A. Grade Resistance \& Gradeability}

Gradeability didefinisikan sebagai grade maksimum kendaraan yang bisa di toleransi tanpa kehilangan kecepatan gerak. Biasanya, kemampuan menanjak didefinisikan pada gigi tertinggi (Hanbook Komatsu, 2009) Rata-rata penggunaannya, gradeability terjadi pada torsi puncak di gigi tertinggi yang seharusnya dicapai, rata-rata pada grade $1,8 \%$ atau minimum $1,5 \%$.

Dalam penelitian Pranoto, H (2015) di istilah alat berat, Gradeability didefinisikan sebagai kemampuan alat berat (traktor atau truck) untuk beroperasi pada lokasi kemiringan (slope) terutama pada saat mendaki / menanjak dalam beberapa variasi sudut kemiringan dalam satuan \%. Variable yang di gunakan dalam perhitungan gradeability cukup komplek. (Pranoto, H., 2015) Sehingga perhitungan ini menjadi penting disaat seorang engineer tambang harus mendesain tambang maupun jalan tambang (RML,PT, 2011). Kondisi akan menjadi sangat fatal apabila gradeability tidak di kaitkan dalam rancangan mine design. Gradeability dinyatakan dalam \% karena slope atau kemiringan biasanya di wakili dengan Tan $\theta$.

Rumus Gradeability :

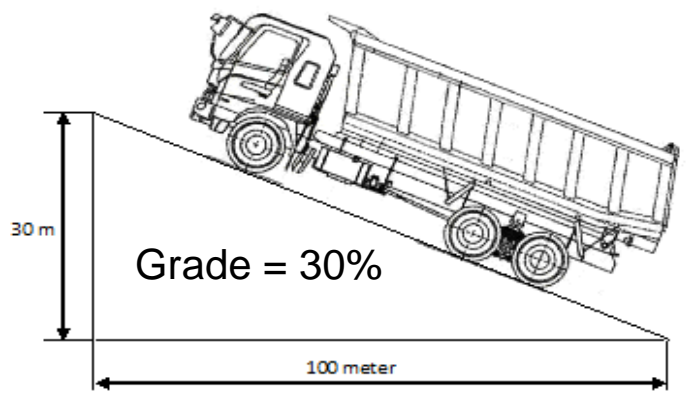

Sumber: Pranoto(2015)

$$
\begin{aligned}
& \text { Gambar } 2 \text { Gradeability Truck } \\
& G=\left[\frac{T x i x \underline{\eta}}{w x r}\right]-\mu r
\end{aligned}
$$

$T$ : Engine Max Torque

$i$ :Transmission Gear Ratio x Rear Axle Gear Ratio

$\dot{\eta}:$ Mechanical Effisien

$\mu r:$ Coeffisien of rolling resistance

$w$ : Gross Vehicle Weight

$r$ : Dynamic Radius of Tire

$G$ :Gradeability (\%)

Dalam Handbook Komatsu (2009), Daya Tahanan Kelandaian ( Power Grade Resistance) merupakan tenaga yang dibutuhkan untuk menanjak bukit.

Daya untuk tahanan kelandaian di formulakan sbb :

$$
\mathrm{Pg}=\frac{G x G V W x V}{37.5 n n}
$$

Dimana ;

$\mathrm{Pg} \quad=$ Power grade resistance

$\mathrm{G}=$ Grade dalam satuan $\%$

$\mathrm{v} \quad=$ Kecepatan dalam satuan $\mathrm{mph}$

GVW = Berat kendaraan / Gross Vehicle Weight dalam $\mathrm{lb}$

$37.500=$ Konstanta 


\section{B. Fuel Consumption}

Perhitungan fuel consumption untuk kecepatan maksimum dapat menggunakan dengan rumus kecepatan maximum, karena satuan dari fuel consumption adalah $\mathrm{km} / \mathrm{liter}$ artinya berapa jarak tempuh yang sudah dilalui dibanding konsumsi bahan bakarnya. Untuk aktifitas penambangan tidak hanya jarak tempuh yang di perhitungkan tetapi waktu operasi mesin menjadi hal yang sangat berpengaruh. Oleh sebab itu perhitungan fuel consumption dalam satuan liter per jam. Artinya seberapa besar volume bahan bakar digunakan dalam satuan waktu. (Warsowiwoho B.M.E., et al, 1982)

Persamaan Fuel Consumption dapat dirumuskan $\mathrm{sbb}$ :

$\mathrm{a}=\frac{P_{\operatorname{eng} x \mathrm{fb}}}{1000 x \rho}$

Dimana,

$\mathrm{a}$ = fuel consumption dalam liter / jam

$\mathrm{P}_{\mathrm{eng}}=$ Total daya engine dalam satuan HP

$\mathrm{fb}=$ Minimum fuel consumption dalam satuan gr/HP.h

$\rho=$ Massa jenis bahan bakar solar, dalam satuan $\mathrm{gr} / \mathrm{ml}$

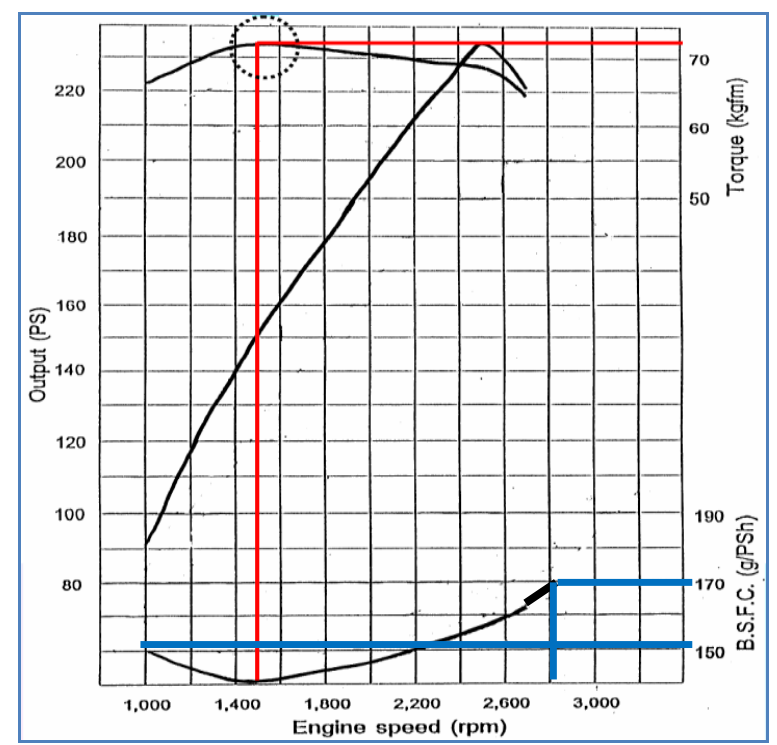

Sumber: Pengolahan Data (2019)

Gambar 3 Minimum fuel rate ( $\mathrm{fb}$ )

Daya adalah kemampuan untuk mengubah suatu bentuk energi menjadi suatu bentuk energi lain dalam waktu tertentu. Perhitungan daya yang dibutuhkan tergantung pada gaya- gaya yang bekerja pada kendaraan tersebut. Daya merupakan usaha yang dilakukan pada setiap satuan waktu. Sehingga rumus dasar daya adalah

Dimana ;

$\mathrm{P}=$ Daya $(\mathrm{HP})$

$\mathrm{W}=$ Usaha $(\mathrm{KJ})$

$\mathrm{t}=$ Waktu (jam)

\section{Regresi Linier Berganda}

Regresi linier berganda merupakan model persamaan yang menjelaskan hubungan satu variabel tak bebas/ response $(\mathrm{Y})$ dengan dua atau lebih variabel bebas/ predictor (X1, $\mathrm{X} 2, \ldots \mathrm{Xn})$. Tujuan dari uji regresi linier berganda adalah untuk memprediksi nilai variable tak bebas/ response (Y) apabila nilainilai variabel bebasnya/ predictor $(\mathrm{X} 1, \mathrm{X} 2, \ldots$, $\mathrm{X}_{\mathrm{n}}$ ) diketahui. (Irianto,H.A , 2010). Disamping itu juga untuk dapat mengetahui bagaimanakah arah hubungan variabel tak bebas dengan variabel - variabel bebasnya. Persamaan regresi linier berganda secara matematik diekspresikan oleh :

$\mathrm{Y}=\mathrm{a}+\mathrm{b} 1 \mathrm{X} 1+\mathrm{b} 2 \mathrm{X} 2+\ldots+\mathrm{bn} \mathrm{Xn}$

Dimana :

$\mathrm{Y}=$ variable tak bebas (nilai variabel yang akan diprediksi)

$\mathrm{a}=$ konstanta

$\mathrm{b} 1, \mathrm{~b} 2, \ldots, \mathrm{bn}=$ nilai koefisien regresi

$\mathrm{X}_{1}, \mathrm{X}_{2}, \ldots, \mathrm{X}_{\mathrm{n}}=$ variable bebas

Bila terdapat 2 variable bebas, yaitu $\mathrm{X} 1$ dan $\mathrm{X}_{2}$, maka bentuk persamaan regresinya adalah

$\mathrm{Y}=\mathrm{a}+\mathrm{b}_{1} \mathrm{X}_{1}+\mathrm{b}_{2} \mathrm{X}_{2}$

\section{Jenis Data}

Dalam penelitian ini jenis data yang digunakan adalah :

- Data primer : data dari observasi dan pengujian data sample

- Data sekunder : data dari pabrik pembuat truk yang berhuBungan dengan specifikasi alat 


\section{E. Metode Penelitian}

Metode yang akan dilakukan dalam penelitian ini adalah :

- Observasi : menguji data sample dengan beberapa variasi parameter

- Studi pustaka : pendekatan teknis dan teoritis mengenai performa alat

\section{F. Variabel Penelitian}

Variabel penelitan ini ada dua jenis yaitu :

- Variable dependen : yaitu variable terikat yang dalam hal ini adalah fuel consumption

- Variable independent : yaitu variable bebas yang dalam hal ini adalah kecepatan, grade jalan dan perbandingan gigi transmisi

\section{G. Instrumen Penelitian}

Penelitan ini membutuhkan beberapa instrument untuk membantu dalam hal pengujian lapangan, pengolahan data dan analisi

\section{Observasi}

Instrument yang digunakan adalah pendekatan mengukur nilai-nilai parameter variable penelitian. Alat yang digunakan adalah :

- Fuel gauge atau alat pengukur volume tangka bahan bakar

- $\quad$ Stopwatch untuk mengukur waktu ritasi alat berat

- Total station untuk mengukur nilai grade jalan

\section{Studi Pustaka}

Intrumen lain adalah menggunakan tools dalam pengolahan data dan analisis data dengan menggunakan MS Excel. Termasuk untuk perhitungan nilai persamaan atau rumus variable penelitian.

\section{H. Populasi dan Sample}

Dalam penelitian ini menggunakan 2 sample dump truk dari 5 populasi Dump truck yang digunakan. Penelitian dilakukan dengan 3 kali pengujian dan tiap pengujian ada 6 kali pengambilan data.

\section{Flowchart Penelitian}

Urutan langkah penetilian dapat digambarkan dalam sebuah flowchart atau diagram alir penelitian dapat dilihat pada Gambar 4:

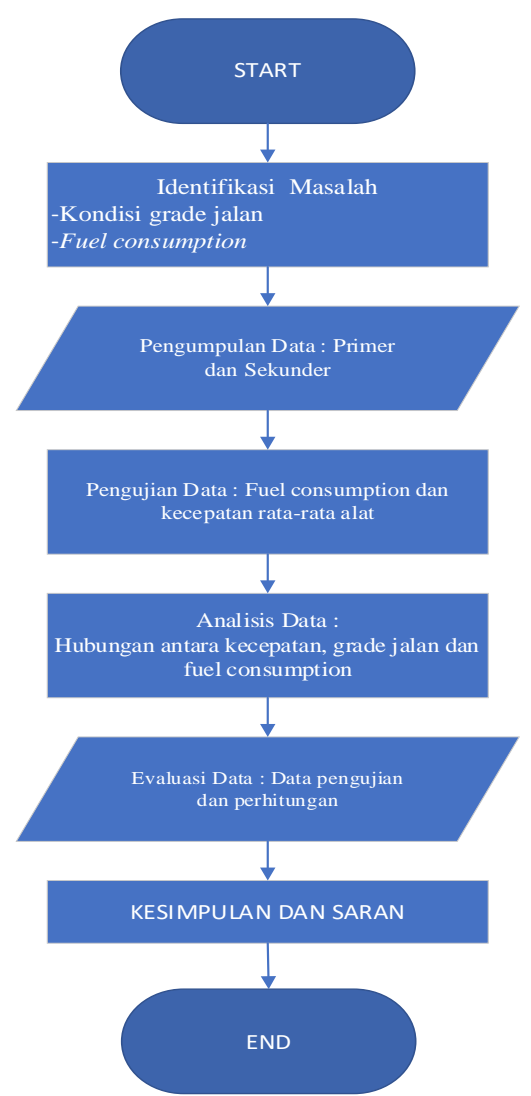

Sumber: Pengolahan Data (2019)

Gambar 4 Flowchart Penelitian

\section{HASIL DAN PEMBAHASAN}

\subsection{Parameter Penelitian}

- Grade jalan : Variasi 8 segmen grade

- Kecepatan : speed 1 - dengan kondisi Low range dan High range

- Gear Ratio Transmisi : kondisi standar gear yaitu $1-8$ rasio.

Tabel 1 Segmen Jalan Pengujian

\begin{tabular}{ccc}
\hline \multicolumn{3}{c}{ JALAN PIT 1 \& 2 } \\
\hline Segment & Grade ( \% ) & Jarak ( m ) \\
\hline A - B & $1.00 \%$ & 300 \\
\hline B - C & $6.20 \%$ & 500 \\
\hline C - D & $4.56 \%$ & 250 \\
\hline
\end{tabular}




\begin{tabular}{ccc}
$\mathrm{D}-\mathrm{E}$ & $6.89 \%$ & 400 \\
\hline $\mathrm{E}-\mathrm{F}$ & $8.10 \%$ & 450 \\
\hline $\mathrm{F}-\mathrm{G}$ & $1.10 \%$ & 150 \\
\hline $\mathrm{G}-\mathrm{H}$ & $1.00 \%$ & 100 \\
\hline $\mathrm{H}-\mathrm{I}$ & $4.13 \%$ & 350 \\
\hline \multicolumn{2}{c}{ Total } & $\mathbf{2 5 0 0}$
\end{tabular}

Sumber: Pengolahan Data (2019)

\section{A. Kondisi Medan Pengujian}

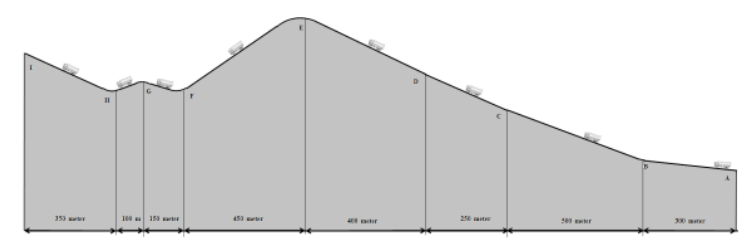

(Sumber : RML,PT, 2011)

Gambar 5 Penampang Segmen Jalan

\section{B. Gear Ratio Transmisi}

Gear Ratio pada transmisi untuk jenis DT Hino JD 260 adalah :

Tabel 2 Perbandingan Gigi Transmisi

\begin{tabular}{cc}
\hline Gigi & $\begin{array}{c}\text { Transmission } \\
\text { Gear Ratio } \\
\text { FM 260 JD }\end{array}$ \\
\hline 1 & 8,829 \\
\hline 2 & 6,281 \\
\hline 3 & 4,644 \\
\hline 4 & 3,478 \\
\hline $\mathbf{5}$ & 2,538 \\
\hline 6 & 1,806 \\
\hline 7 & 1,335 \\
\hline $\mathbf{8}$ & 1 \\
\hline
\end{tabular}

(Sumber : RML,PT, 2011)

\subsection{Hasil Perhitungan Gradeability}

Dalam kasus penelitian ini jalan yang dilalui truck adalah jalan yang ber-contour dimana ada 8 segmen grade jalan, baik itu tanjakan maupun turunan. Oleh sebab itu kehandalan truk untuk menajak harus diperhitungkan lebih dulu. Tabel dibawah ini adalah tabel mengenai range/rentang nilai gradeablility tiap gear ratio pada transmisi.

Tabel 3 Gradeability DT Hino

\begin{tabular}{ccc}
\multicolumn{3}{c}{ Tabel 3 Gradeability DT Hino } \\
\hline Model & Gear T/M & Gradeability \\
\hline
\end{tabular}

\begin{tabular}{lrrrr} 
& & & \multicolumn{1}{c}{$\%$} & Derajat \\
\hline FM260JD & 1 & 8,829 & 0,236 & 13,5 \\
\hline FM260JD & 2 & 6,281 & 0,152 & 8,7 \\
\hline FM260JD & 3 & 4,644 & 0,1 & 5,7 \\
\hline FM260JD & 4 & 3,478 & 0,061 & 3,5 \\
\hline FM260JD & 5 & 2,538 & 0,032 & 1,8 \\
\hline FM260JD & 6 & 1,806 & 0,01 & 0,6 \\
\hline FM260JD & 7 & 1,335 & $-0,005$ & $-0,3$ \\
\hline FM260JD & 8 & 1 & $-0,016$ & $-0,9$ \\
\hline
\end{tabular}

(Sumber : RML,PT, 2011)

Jika dibandingkan dengan grade jalan pada potongan melintang diatas, pada gear 1, 2 dan 3 mampu dengan mudah menanjak atau mendaki, dimana segmen tertinggi adalah di segmen E-F yaitu $8,1 \%$

\subsection{Hasil Pengujian Fuel Consumption}

Dalam pengujian fuel consumption ini dilakukan dengan cara mengukur dengan fuel gauge dan sesuai dengan rute tempuh yang ditetapkan oleh mine design. Data ini ada actual, sehingga peneliti akan mengkomparasi dengan perhitungan rumus, dengan nilai data input dalam rumus juga actual. Pengujian dengan memperhitungkan 2 kondisi yaitu loaded dan unloaded

a. Pengujian I fuel consumption : Pengujian dilakukan 2 truk dengan 6 ritasi tiap truck nya. Hasilnya adalah :

Tabel 4. Pengujian Fuel Consumption I

\begin{tabular}{cccc}
\hline $\begin{array}{c}\text { Jumlah } \\
\text { Lap }\end{array}$ & Kondisi & $\begin{array}{c}\text { Jarak } \\
\text { (km) }\end{array}$ & $\begin{array}{c}\text { Volume Fuel } \\
\text { (Liter) }\end{array}$ \\
\hline 12 & Muatan & 30 & 39,5 \\
\hline 12 & Kosongan & 30 & 10,5 \\
\hline
\end{tabular}

(Sumber: Pengolahan Data 2019)

b. Pengujian II fuel consumption : Pengujian dilakukan 2 truk dengan 6 ritasi tiap truck nya. Hasilnya adalah :

Tabel 5. Pengujian Fuel Consumption II

\begin{tabular}{cccc}
\hline $\begin{array}{c}\text { Jumlah } \\
\text { Lap }\end{array}$ & Kondisi & $\begin{array}{c}\text { Jarak } \\
(\mathbf{k m})\end{array}$ & $\begin{array}{c}\text { Volume Fuel } \\
\text { (Liter) }\end{array}$ \\
\hline 12 & Muatan & 30 & 38,5 \\
\hline 12 & Kosongan & 30 & 9,5 \\
\hline
\end{tabular}

(Sumber: Pengolahan Data 2019)

c. Pengujian III 
fuel consumption : Pengujian dilakukan 2 truk dengan 6 ritasi tiap truck nya. Hasilnya adalah :

Tabel 6. Pengujian Fuel Consumption III

\begin{tabular}{cccc}
\hline $\begin{array}{c}\text { Jumlah } \\
\text { Lap }\end{array}$ & Kondisi & $\begin{array}{c}\text { Jarak } \\
(\mathbf{k m})\end{array}$ & $\begin{array}{c}\text { Volume Fuel } \\
\text { (Liter) }\end{array}$ \\
\hline 12 & Muatan & 30 & 40 \\
\hline 12 & Kosongan & 30 & 9,5 \\
\hline
\end{tabular}

(Sumber: Pengolahan Data 2019)

Rata-rata dari 3 kali pengujian adalah :

Tabel 7 Rerata Pengujian Fuel Consumption

\begin{tabular}{cccc}
\hline $\begin{array}{c}\text { Jumlah } \\
\text { Lap }\end{array}$ & Kondisi & $\begin{array}{c}\text { Jarak } \\
(\mathbf{k m})\end{array}$ & $\begin{array}{c}\text { Volume } \\
\text { Fuel } \\
\text { (Liter) }\end{array}$ \\
\hline 36 & Muatan & 90 & 118 \\
\hline 36 & Kosongan & 90 & 29,5 \\
\hline
\end{tabular}

(Sumber: Pengolahan Data 2019)

Dari hasil penelitian tersebut digambarkan dengan control Gambar 6 Pemakaian Fuel Kosongan Untuk pemakaian fuel kosongan trend meningkat, walaupun secara normal masih masuk dalam batas atas dan bawah.

\subsection{Hasil Speed \& Grade per Segmen}

Hasil pengujian kecepatan dari 2 sample yang dilakukan dengan membandungkan nilai grade jalan sangat bervariasi yaitu

Tabel 8. Hasil Kec. Rerata vs Grade

\begin{tabular}{|c|c|c|c|c|c|}
\hline Segment & & Grade & & $\begin{array}{r}\text { KECEPATAN } \\
(\mathrm{km} / \mathrm{j}\end{array}$ & RATA \\
\hline Muatan & Kosongan & $\begin{array}{l}\text { Jarak } \\
\text { (m) }\end{array}$ & \multirow[b]{2}{*}{ MUATAN } & \multirow[b]{2}{*}{ KOSONGAN } & \multirow[b]{3}{*}{19,7} \\
\hline & & & & & \\
\hline$A-B$ & $1 \%$ & $-1 \%$ & 300 & 14,4 & \\
\hline$B-C$ & $6.20 \%$ & $-6.20 \%$ & 500 & 10 & 28,2 \\
\hline$C-D$ & $4.56 \%$ & $-4.56 \%$ & 250 & 10,8 & 26,1 \\
\hline$D-E$ & $6.89 \%$ & $-6.89 \%$ & 400 & 10,5 & 26,7 \\
\hline$t, \mathrm{E}-\mathrm{F}$ & $-8,10 \%$ & 0,081 & 450 & 24,6 & 16,7 \\
\hline $\ln _{F-G}$ & $1.10 \%$ & $-1.10 \%$ & 150 & 21,6 & 23 \\
\hline $\mathrm{is}^{\mathrm{G}-\mathrm{H}}$ & $-1.00 \%$ & 0,01 & 100 & 19,8 & 20,7 \\
\hline $\mathrm{H}-\mathrm{I}$ & $4.13 \%$ & $-4.13 \%$ & 350 & 13,8 & 24,8 \\
\hline & RATA-RATA & & 2500 & 15,7 & 23,2 \\
\hline
\end{tabular}

(Sumber: Pengolahan Data 2019)

Jika dikonversikan menjadi perbandingan gigi pada transmisi adalah sbb :

Tabel 9 Gear Ratio Muatan

\begin{tabular}{ccccc}
\hline \multicolumn{3}{c}{ JALAN PIT 1 \& 2 } & \multicolumn{2}{c}{ MUATAN } \\
\hline \multirow{2}{*}{ Segment } & Grade & Jarak & \multirow{2}{*}{ Gear } & \multirow{2}{*}{ Ratio } \\
\cline { 2 - 4 } & $\mathbf{( \% )}$ & $\mathbf{( ~ m ~ ) ~}$ & & \\
\hline A - B & $1.00 \%$ & 300 & 5 & 2,54 \\
\hline B - C & $6.20 \%$ & 500 & 3 & 4,64 \\
\hline C - D & $4.56 \%$ & 250 & 4 & 3,48 \\
\hline D - E & $6.89 \%$ & 400 & 3 & 4,64 \\
\hline E - F & $8.10 \%$ & 450 & 6 & 1,81 \\
\hline F - G & $1.10 \%$ & 150 & 5 & 2,54 \\
\hline G - H & $1.00 \%$ & 100 & 5 & 2,54 \\
\hline H - I & $4.13 \%$ & 350 & 3 & 4,64 \\
\hline \multicolumn{2}{c}{ Total } & 2500 & &
\end{tabular}

(Sumber: Pengolahan Data 2019)

(Sumber: Pengolahan Data 2019) 
Tabel 10 Gear Ratio Kosongan

\begin{tabular}{ccccc}
\hline Segment & $\begin{array}{c}\text { Grade } \\
(\boldsymbol{\%})\end{array}$ & $\begin{array}{c}\text { Jarak } \\
(\mathbf{m})\end{array}$ & Gear & Ratio \\
\hline A - B & $1.00 \%$ & 300 & 6 & 1,81 \\
\hline B - C & $6.20 \%$ & 500 & 7 & 1,34 \\
\hline C - D & $4.56 \%$ & 250 & 7 & 1,34 \\
\hline D-E & $6.89 \%$ & 400 & 7 & 1,34 \\
\hline E-F & $8.10 \%$ & 450 & 6 & 1,81 \\
\hline F- G & $1.10 \%$ & 150 & 7 & 1,34 \\
\hline G-H & $1.00 \%$ & 100 & 7 & 1,34 \\
\hline H-I & $4.13 \%$ & 350 & 7 & 1,34 \\
\hline Total & & 2500 & & \\
\hline
\end{tabular}

(Sumber: Pengolahan Data 2019)

Dengan pendekatan rumus fuel consumption seperti yang ada di teori, dengan data actual yang ada dan dengan parameter grade jalan, kecepatan actual, jarak tempuh actual, daya actual (daya grade, rolling, aerodinamis dll) diperoleh data hubungan kecepatan dengan fuel consumption adalah sbb

Tabel 11 Kecepatan vs F/C Muatan

\begin{tabular}{ccccc}
\hline Segment & Grade & $\begin{array}{c}\text { Jarak } \\
\text { (meter) }\end{array}$ & $\begin{array}{c}\text { Kecepatan } \\
\text { Km/jam }\end{array}$ & $\begin{array}{c}\text { Fuel } \\
\text { Consumption } \\
\text { Liter/jam }\end{array}$ \\
\hline A - B & $1,0 \%$ & 300 & 14,4 & 9,67 \\
\hline B - C & $6,2 \%$ & 500 & 10,0 & 19,49 \\
\hline C - D & $4,6 \%$ & 250 & 10,8 & 16,32 \\
\hline D - E & $6,9 \%$ & 400 & 10,5 & 22,05 \\
\hline E-F & $-8,1 \%$ & 450 & 24,6 & 11,79 \\
\hline F - G & $1,1 \%$ & 150 & 21,8 & 16,02 \\
\hline G-H & $-1,0 \%$ & 100 & 19,7 & 9,27 \\
\hline H-I & $4,1 \%$ & 350 & 13,8 & 20,13 \\
\hline Total & & $\mathbf{2 5 0 0}$ & $\mathbf{1 5 , 7}$ & $\mathbf{1 5 , 6}$ \\
\hline
\end{tabular}

(Sumber: Pengolahan Data 2019)

Tabel 12 Kecepatan vs F/C Kosongan

\begin{tabular}{ccccc}
\hline $\begin{array}{c}\text { Segmen } \\
\mathbf{t}\end{array}$ & Grade & $\begin{array}{c}\text { Jarak } \\
\text { (meter } \\
\text { ) }\end{array}$ & $\begin{array}{c}\text { Kecepata } \\
\mathbf{n} \\
\text { Km/jam }\end{array}$ & $\begin{array}{c}\text { Fuel } \\
\text { Consumption } \\
\text { Liter/jam }\end{array}$ \\
\hline A-B & $1,00 \%$ & 300 & 19,8 & 4,18 \\
B-C & $6,20 \%$ & 500 & 28,1 & 5,38 \\
\hline C-D & $4,60 \%$ & 250 & 25,9 & 4,67 \\
\hline$D-E$ & $6,90 \%$ & 400 & 26,6 & 4,54 \\
\hline E-F & - & 450 & 16,6 & 15,71 \\
\hline
\end{tabular}

\begin{tabular}{|c|c|c|c|c|}
\hline$F-G$ & $1,10 \%$ & 150 & 22,7 & 5,41 \\
\hline $\mathrm{G}-\mathrm{H}$ & $\begin{array}{c}- \\
1,00 \% \\
\end{array}$ & 100 & 20,9 & 6,81 \\
\hline $\mathrm{H}-\mathrm{I}$ & $4,10 \%$ & 350 & 24,9 & 4,62 \\
\hline Total & & 2500 & 23,2 & 6,4 \\
\hline
\end{tabular}

(Sumber: Pengolahan Data 2019)

Hasil penelitian berkaitan dengan segmen grade jalan dengan volume total dari semua pengujian adalah sbb :

Tabel 13 Pemakaian Total Fuel Muatan

\begin{tabular}{ccccc}
\hline Segment & Grade & $\begin{array}{c}\text { Jarak } \\
\text { Tempuh } \\
(\mathbf{K m})\end{array}$ & $\begin{array}{c}\text { Waktu } \\
\text { (Jam) }\end{array}$ & $\begin{array}{c}\text { Volume } \\
\text { (Liter) }\end{array}$ \\
\hline A - B & $1,0 \%$ & 10,8 & 0,8 & 7,3 \\
\hline B - C & $6,2 \%$ & 18,0 & 1,8 & 35,0 \\
\hline C-D & $4,6 \%$ & 9,0 & 0,8 & 13,7 \\
\hline D - E & $6,9 \%$ & 14,4 & 1,4 & 30,2 \\
\hline E - F & $-8,1 \%$ & 16,2 & 0,7 & 7,8 \\
\hline F - G & $1,1 \%$ & 5,4 & 0,2 & 4,0 \\
\hline G - H & $-1,0 \%$ & 3,6 & 0,2 & 1,7 \\
\hline H-I & $4,1 \%$ & 12,6 & 0,9 & 18,4 \\
\hline Total & & $\mathbf{9 0}$ & $\mathbf{6 , 8}$ & $\mathbf{1 1 7 , 9}$ \\
\hline
\end{tabular}

(Sumber: Pengolahan Data 2019)

Tabel 14 Pemakaian Total Fuel Kosongan

\begin{tabular}{|c|c|c|c|c|}
\hline Segment & Grade & $\begin{array}{c}\text { Jarak } \\
\text { Tempuh } \\
\text { (Km) }\end{array}$ & $\begin{array}{c}\text { Waktu } \\
\text { (Jam) }\end{array}$ & $\begin{array}{c}\text { Volume } \\
\text { (Liter) }\end{array}$ \\
\hline$A-B$ & $1,0 \%$ & 10,8 & 0,55 & 2,3 \\
\hline$B-C$ & $6,2 \%$ & 18,0 & 0,64 & 3,5 \\
\hline$C-D$ & $4,6 \%$ & 9,0 & 0,35 & 1,6 \\
\hline$D-E$ & $6,9 \%$ & 14,4 & 0,54 & 2,5 \\
\hline$E-F$ & $-8,1 \%$ & 16,2 & 0,97 & 15,3 \\
\hline$F-G$ & $1,1 \%$ & 5,4 & 0,24 & 1,3 \\
\hline $\mathrm{G}-\mathrm{H}$ & $-1,0 \%$ & 3,6 & 0,17 & 1,2 \\
\hline $\mathrm{H}-\mathrm{I}$ & $4,1 \%$ & 12,6 & 0,51 & 2,3 \\
\hline Total & & 90 & 4,0 & 29,90 \\
\hline
\end{tabular}

\subsection{Analisis Regresi Berganda}

Dalam analisis regresi berganda, data variable terikat adalah fuel consumption sedangkan variable bebasnya ada 2 variable X1 dan X2 . Dimana persamaan liniernya akan menjadi :

$\mathrm{Y}=\mathrm{a}+\mathrm{b}_{1} \mathrm{X}_{1}+\mathrm{b}_{2} \mathrm{X}_{2}$

$\mathrm{Y}=$ Fuel consumption

$\mathrm{X} 1=$ Grade Jalan tambang

X2 = Gear Ratio Transmisi

Pengaruh Gear Ratio Transmisi dan Grade Jalan Terhadap Fuel ConSumption Truck Batubara dengan Pendekatan 
Untuk persamaan pada kondisi Muatan :

$\mathrm{Y}=5,92-14,62 \cdot \mathrm{X} 1+2,8 \cdot \mathrm{X} 2$

Dimana :

Nilai a $=5,92$

Nilai b1 $=-14,62$

Nilai b2 $=2,80$

Koefisien Determinannya $\left(\mathrm{r}^{2}\right)=0,6035=$ $60,35 \%$

Dari hasil ini menunjukkan bahwa variabel X2 mempunyai pengaruh lebih kuat disbanding variable X1 karena nilai b2 > b1. Sedangkan secara signikan dari nilai akhir (Y) adalah dipengaruhi $60,35 \%$ dari kedua variabel $\mathrm{X} 1$ dan $\mathrm{X} 2$, dan sisanya $39,65 \%$ dipengaruhi oleh faktor lain, bisa skill operator, kondisi mesin dll.

Untuk persamaan pada kondisi Kosongan :

Dari hasil perhitungan menggunakan analisis regresi linier berganda dengan jumlah data adalah 96, maka di peroleh persamaan sbb :

$\mathrm{Y}=0,44+39,15 \cdot \mathrm{X} 1+3,86 . \mathrm{X} 2$

\section{Dimana :}

Nilai a $=0,44$

Nilai b1 $=39,15$

Nilai b2 $=3,87$

Koefisien Determinannya $\left(r^{2}\right)=0,8778=$ $87,78 \%$

Dari hasil ini untuk kondisi kosongan menunjukkan bahwa variabel X1 mempunyai pengaruh lebih kuat disbanding variable X2 karena nilai b1 > b2. Sedangkan secara signikan dari nilai akhir (Y) adalah dipengaruhi $87,78 \%$ dari kedua variabel X1 dan X2, dan sisanya $12,22 \%$ dipengaruhi oleh faktor lain, bisa skill operator, kondisi mesin dll.

Jika dibandingkan kondisi muatan dengan kondisi kosongan, variable $\mathrm{X} 1$ dan $\mathrm{X} 2$ cukup signifikan mempengaruhi pemakaian bahan bakar atau fuel consumption.

Ada kemungkinan factor lain yang menyumbang pengaruh kuat adalah skill operator, karena kondisi muatan $75 \%$ jalannya menanjak sehingga membutuhkan skill yang baik untuk pengoperasiannya.

\section{KESIMPULAN DAN SARAN}

Dari hasil penelitian ini dapat disimpulkan sebagai berikut :

1. Fuel consumption hasil pengukuran dengan fuel gauge tidak jauh berbeda dengan hasil perhitungan actual dengan menggunakan pendekatan rumus praktis

2. Gear ratio transmisi memiliki pengaruh lebih kuat terhadap pemakaian bahan bakar dibandingkan dengan kondisi grade jalan yang bervariasi untuk kondisi muatan (loaded)

3. Grade jalan memiliki korelasi pengaruh lebih kuat terhadap pemakaian bahan bakar disbanding dengan gear ratio.

4. Variable Grade jalan dan gear ratio transmisi masing-masing memiliki tingkat pengaruh $87,75 \%$ dan $60,35 \%$. Hal ini menunjukkan bahwa kedua varibel sangat mempengaruhi pemakaian bahan bakar (fuel).

\section{DAFTAR PUSTAKA}

Elevli, S., \& Elevli, B. "Performance measurement of mining equipments by utilizing OEE". Acta Montanistica Slovaca, 15(2), (2010), 95.

Hagendoorm, J.J.M 1992, Konstruksi Mesin 2, Jakarta, PT Rosda Jayaputra

Irianto,H.A. (2010). Statistik Konsep Dasar, Aplikasi dan Pengembangannya. Edisi keempat. Perenadamedia. Jakarta

Komatsu. (2009). Specification \& Application Handbook. Edition $30^{\text {th }}$, Japan.

Nel S, Kizil MS and Knights P (2011). Improving Truck-Shovel Matching, $35^{\text {th }}$ APCOM Symposium, Wollongong, NSW 381-391.

Paduloh et al. (2020). Analysis Of Productivity Based On Kpi Case Study Automotive Paint Industry. Journal of Engineering and Management in Industrial System, $8(1), \mathrm{p} 1-12$

Pranoto, H. (2015). Efisiensi Power Engine Truck Pergerakan Dinamis dengan Mengubah Ratio Final Drive Gear pada Truck Kapasitas 30 Ton. Sinergi. 19(1). 45-50 
RML,PT, 2011, "Modul Pelatihan Aplikasi Alat Berat di Pertambangan", Edisi 12011, Bekasi Jawa Barat

RML,PT, 2013, "Modul Pelatihan New QC Leader", Edisi 1-2013, Bekasi Jawa Barat

Ram Prasad Choudhary, 2015, OPTIMIZATION OF LOAD-HAULDUMP MINING SYSTEM BY OEE AND MATCH FACTOR FOR SURFACE MINING, International Journal of Applied Engineering and Technology ISSN: 2277-212X (Online) An Open Access, Online International Journal Available 2015 Vol. 5 (2) April-June, pp. 96

Sularso \& Suga, K. (2002). Dasar Perencanaan dan Pemilihan Elemen Mesin. Jakarta: PT Pradnya Paramita.

Salim, H.A. Abbas. 2012. Manajemen Transportasi. Jakarta: PT. Rajagrafindo Persada

Warsowiwoho B.M.E., dan Harahap, Gandhi. 1982. Bahan Bakar Pelumas Pelumasan Servis. Jakarta: Pradnya Paramita

Waqas, M. (2013). Measuring Performance of Mining Equipments Used in Cement Industry by Using Overall Equipment Effectiveness (OEE). MSc. Thesis, Department of Mining Engineering, University of Engineering \& Technology, Lahore, Pakistan. 